JASEM ISSN 1119-8362

All rights reserved
Full-text Available Online at www.bioline.org.br/ja
J. Appl. Sci. Environ. Mgt. June, 2006

Vol. 10 (2) 19 - 21

\title{
Diurnal dynamics of water quality parameters in an aquaculture system based on recirculating green water technology
}

\author{
*11AFTAB ALAM; YOUSEF S. AL-HAFEDH \\ Natural Resources \& Environment Research Institute, King Abdulaziz City for Science \& Technology, \\ P.O. Box 6086, Riyadh 11442, Saudi Arabia
}

\begin{abstract}
Recirculating greenwater aquaculture technology is an appropriate method for producing commercial quantities of tilapia in areas where water is scarce. Greenwater systems achieve better fish production, more than $90 \%$ water recycling and nutrient utilization. This study was designed to address the diurnal dynamics of certain water quality parameters in greenwater system. Culture tanks were stocked at a density of $40 \mathrm{fish} / \mathrm{m}^{3}$ with mixed-sex Nile tilapia, Oreochromis niloticus fingerlings and fed ad libitum with floating pellets containing 34\% protein. The water temperature was kept $28 \pm 1^{\circ} \mathrm{C}$, aeration was provided and sludge was collected twice daily. Values of critical chemical parameters in the water were found to be well within the acceptable limits based on diurnal water sampling. @JASEM
\end{abstract}

Deprived freshwater resources and harsh climatic conditions limit the development of freshwater aquaculture in Saudi Arabia. However, an increasing demand for fresh fish is putting pressure for the establishment of water recirculating aquaculture technologies that intensify fish production and maximize water recycling. Recirculating greenwater aquaculture technology has been found to be an appropriate method for producing commercial quantities of tilapia in locations that have environmental constraints (Cole et al. 1997; Rakocy et al. 2000). Greenwater aquaculture systems aim to increase fish production, proper nutrient utilization, maximum water recycling and least water wastage. Water is green in greenwater systems because of the development of photosynthetic algae in the water column. Uneaten feed, fecal matter of the fish and dead algae is removed from the system in the form of sludge. Air-lift pumping combined with a numbers of air diffusers keep some minute particles, detritus, feces and plankton in constant circulation. The nitrifying bacteria colonize this floating substrate and oxidize toxic ammonia into relatively harmless nitrate $\left(\mathrm{NO}_{3}-\mathrm{N}\right)$ by creating a suspended growth treatment process (Rakocy et al. 2000). The process maintains adequate water quality for tilapia while recycling waste nutrients into plankton and bacteria. Elimination of the need for a biofilter not only cuts capital costs but also the management and maintenance needs of greenwater systems (Martin 2000). Water losses in greenwater systems are from evaporation and sludge removal. Small-scale greenwater systems require usually less than $1 \%$ of the total water volume per day.

Water recirculating greenwater technology for semiintensive fish culture and maximum water recycling was developed in Saudi Arabian climate to produce Nile tilapia. Overall system performance and fish production is determined by water quality, thus, major water quality parameters were regularly tested in order to establish the success of this system. This paper presents diurnal variation of certain water quality parameters in greenwater system aiming at dynamics of these parameters through 24 hours period. The experiment is expected to contribute some insight on the effects of physiological activities of the fish on water chemistry in a diurnal cycle. Determination of the periods of peak concentrations of major water quality parameters would be helpful to improve the performance of greenwater system by altering the management practices and minimizing the stress to fish.

\section{MATERIALS AND METHODS}

Each of the three replicates of the greenwater system had one fish culture tank (water volume $10.0 \mathrm{~m}^{3}$ ) and one cone bottomed cylindrical clarifier (water volume $0.47 \mathrm{~m}^{3}$ ) for solid settling. An inline airlift pump was installed before the cone clarifier to recirculate the water between the fish culture tank and cone clarifier at a rate of $7-8 \mathrm{~L} /$ minute. Fish culture tanks had a $3 \%$ slope towards the center of the bottom drain to enhance the solid removal. Water from central bottom drain of fish culture tank pumped to the cone clarifier through airlift pump. Cone clarifier had two baffles to aid the settling of detritus, feces and dead cells. The sludge was drained twice daily from the clarifier and the water lost in the sludge collection and due to evaporation was added back to the system. The outflow of the cone clarifier flows by gravity into the fish rearing tank through a 7.62 cm diameter pipe.

Fish tanks were stocked at a density of $40 \mathrm{fish} / \mathrm{m}^{3}$ with mixed sex Nile tilapia, Oreochromis niloticus (average weight $29.26( \pm 6.75) \mathrm{g} / \mathrm{fish})$, on $22^{\text {nd }}$ November 2001. Floating pellets containing 34\% protein and 5\% fat were used to feed the fish to satiation for 20 minutes twice daily (0800 and 1600 hours). The water temperature was maintained at $28 \pm 1^{\circ} \mathrm{C}$ by installing heaters with thermostats. Water flow rate was approximately $7.0 \mathrm{~L} /$ minute so that entire volume of the culture tank circulates through the clarifier once in 24 hours. Fifteen small fish (approximately $30 \mathrm{~g}$ each) were stocked in each clarifier to enhance the sludge settling. Aeration was provided to the water in 
fish tanks using 28 air diffusers $(7.6 \mathrm{~cm}$ x $2.5 \mathrm{~cm}$ x 2.5) connected to an air blower.

Water sampling was started on 21 May 2002 when the system was at close to its carrying capacity. Samples were collected in triplicate from 08:00 hrs till 06:00 hrs next day at an interval of every 2 hours from each of the fish rearing tanks and outlets of the cone clarifiers. Samples were analyzed for TAN (total ammonia nitrogen), $\mathrm{NO}_{2}-\mathrm{N}$ (nitrite-nitrogen), $\mathrm{NO}_{3}-\mathrm{N}$ (nitrate-nitrogen) by using DR 4000 spectrophotometer (Hach, Loveland, Colorado). Values of water temperature, $\mathrm{pH}$, DO (dissolved oxygen), total suspended solids (TDS), total, free $\mathrm{CO}_{2}$ (carbon dioxide) were also determined following standard methods (APHA 1992).

\section{RESULTS AND DISCUSSION}

Fluctuations in some major water quality parameters over 24 hours period are computed in Table 1. Results show a drop in $\mathrm{pH}$ values during night when carbon dioxide increases. TAN tends to increase usually after the feeding and in the night. DO fluctuated moderately, however, aeration kept its levels well above $4 \mathrm{mg} / \mathrm{L}$ throughout the diurnal cycle. Total ammonia nitrogen (TAN) consists of two fractions, un-ionized ammonia $\left(\mathrm{NH}_{3}\right)$ and ionized ammonia $\left(\mathrm{NH}_{4}^{+}\right)$of which, the former is extremely toxic to fish. The proportion of
TAN in the un-ionized form is dependent upon the $\mathrm{pH}$ and temperature of the water. At higher $\mathrm{pH}$ and water temperature the percentage of toxic unionized ammonia is also high. Concentration of $\mathrm{NH}_{3}-\mathrm{N}$ over the 24 hours period, calculated from the mole fraction values of unionized ammonia for different temperature and $\mathrm{pH}$ following Huguenin and Colt (1989), were low due to the low $\mathrm{pH}$ of the water (Table 1 ). $\mathrm{NH}_{3}-\mathrm{N}$ values, recorded in this study, were lower than the $0.7 \mathrm{mg} / \mathrm{L}$ reported by Leclerq and Hopkins (1985) and were much less than the lethal levels of $2.4 \mathrm{mg} / \mathrm{L}$ (48h-LC50) reported by Redner and Stickney (1979) for blue tilapia, Oreochromis aureus, and $2.88 \mathrm{mg} / \mathrm{L}$ (96-hour-LC50) reported by Daud et al. (1988) for red tilapia, Oreochromis mossambicus X O. niloticus fry. Nitritenitrogen $\left(\mathrm{NO}_{2}-\mathrm{N}\right)$ and nitrate-nitrogen $\left(\mathrm{NO}_{3}-\mathrm{N}\right)$ are the products of ammonia oxidation. Aquatic species can tolerate extremely high (greater than $100 \mathrm{mg} / \mathrm{L}$ ) concentrations of $\mathrm{NO}_{3}-\mathrm{N}$ (Ebeling et al. 1993). While nitrite-nitrogen is not as toxic as ammonia-nitrogen, it is harmful to aquatic species and must be removed from the system. According to Atwood et al. (2001), the 96hour median lethal concentration of nitrite- $\mathrm{N}$ to small Nile tilapia was $81 \mathrm{mg} / \mathrm{L}$ compared with $8 \mathrm{mg} / \mathrm{L}$ for large fish. Concentration of $\mathrm{NO}_{2}-\mathrm{N}$ and $\mathrm{NO}_{3}-\mathrm{N}$ was found to be ranging from 0.63 to $0.87 \mathrm{mg} / \mathrm{L}$ and 31.51 and $61.04 \mathrm{mg} / \mathrm{L}$, respectively in the greenwater fish tanks during the diurnal study.

Table 1. Diurnal variation of some chemical parameters in the water of the greenwater fish-rearing tanks in the month of May 2002. Each value is the average of two samples from all three greenwater fish culture tanks. *Un-ionized ammonia $\left(\mathrm{NH}_{3}-\mathrm{N}\right)$ values are calculated from TAN concentration by following Huguenin and Colt (1989).

\begin{tabular}{lcccccccccccc}
\hline $\begin{array}{l}\text { Parameters } \\
\mathrm{mg} / \mathrm{L}\end{array}$ & & \multicolumn{1}{c}{ Time (hrs.) } \\
\hline & $06: 00$ & $08: 00$ & $10: 00$ & $12: 00$ & $14: 00$ & $16: 00$ & $18: 00$ & $20: 00$ & $22: 00$ & $24 ; 00$ & $02: 00$ & $04: 00$ \\
$\mathrm{CO}_{2}$ & 11.3 & 8.2 & 7.4 & 7.6 & 6.9 & 8.1 & 10.3 & 12.6 & 12.5 & 13.7 & 12.4 & 12.1 \\
$\mathrm{DO}$ & 4.1 & 5.6 & 6.2 & 5.8 & 6.5 & 6.1 & 4.8 & 4.2 & 4.5 & 4.1 & 4.3 & 4.1 \\
$\mathrm{pH}$ & 6.2 & 6.1 & 6.6 & 7.3 & 7.1 & 6.8 & 6.4 & 6.1 & 5.8 & 5.9 & 5.9 & 5.8 \\
$\mathrm{TAN}$ & 1.7 & 1.7 & 1.6 & 1.2 & 0.9 & 0.8 & 1.9 & 1.5 & 1.7 & 1.6 & 1.7 & 1.8 \\
$* \mathrm{NH}_{3}-\mathrm{N}$ & 0 & 0.002 & 0.003 & 0.026 & 0.006 & 0.006 & 0.004 & 0.002 & 0.002 & 0 & 0.002 & 0.002 \\
$\mathrm{NO}_{2}-\mathrm{N}$ & 0.63 & 0.65 & 0.69 & 0.69 & 0.83 & 0.86 & 0.87 & 0.84 & 0.85 & 0.86 & 0.86 & 0.74 \\
$\mathrm{NO}_{3}-\mathrm{N}$ & 46.00 & 38.53 & 42.75 & 35.00 & 31.51 & 44.25 & 52.25 & 52.54 & 38.00 & 42.25 & 61.04 & 59.75 \\
$\mathrm{TDS}^{2}$ & 4440 & 4490 & 4820 & 4780 & 4430 & 4360 & 4870 & 4730 & 4360 & 4230 & 4210 & 4260 \\
& & & & & & & & & & & & \\
\hline
\end{tabular}

A minimum DO concentration of $5 \mathrm{mg} / \mathrm{L}$ is required for proper functioning of the recirculating system (Greiner and Timmons 1998). Major source of oxygen is from algal photosynthesis and from wind mixing the air and water. Dissolved oxygen content in the greenwater fish tanks was found to be ranging between 4.1 and 6.5 $\mathrm{mg} / \mathrm{L}$. Accumulation of free $\mathrm{CO}_{2}$ lowers the $\mathrm{pH}$ in recirculating aquaculture systems especially when alkalinity is low. Free $\mathrm{CO}_{2}$ concentration more than 50 $\mathrm{mg} / \mathrm{L}$ is reported to be toxic for the fish species (Heinen et al. 1996). Free $\mathrm{CO}_{2}$ values in the fish rearing tanks of greenwater system were determined to ranging from 6.9 $\mathrm{mg} / \mathrm{L}$ to $13.7 \mathrm{mg} / \mathrm{L}$. Thus, free $\mathrm{CO}_{2}$ concentration 
prevailed much lower during the experimentation than the dangerous limit of this gas in the fish culture water.

The $\mathrm{pH}$ is an important water quality parameter in recirculating systems as toxicity of other compounds to fish, especially ammonia and chlorine, are affected by $\mathrm{pH}$. As $\mathrm{pH}$ decreases, ammonia is converted into a less toxic ammonium form, therefore, the increase in $\mathrm{pH}$ will lead towards the accumulation of ammonia in the system (Lawson 1995). Photosynthesis of phytoplankton, however, removes carbon dioxide during the day thereby maintaining relatively higher $\mathrm{pH}$ values in the day time. Value of $\mathrm{pH}$ were found to drop in the night and recorded to be below 6 in the late hours of the night (Table 1). The controlling factor for $\mathrm{pH}$ in most aquacultural facilities is the relationship between algal photosynthesis, carbon dioxide (CO2), and the bicarbonate (HC03-) buffering system. In the night, respiration by bacteria, plants, and animals results in oxygen consumption and carbon dioxide production, first producing carbonic acid (H2C03), then bicarbonate HC03- and $\mathrm{H}+$ ions; the increase in $\mathrm{H}+$ causes the $\mathrm{pH}$ to drop. During sunlight, respiration continues, but algae use $\mathrm{CO} 2$ for photosynthesis, reducing the abundance of $\mathrm{H}+\mathrm{ions}$, and $\mathrm{pH}$ goes up. The system used groundwater with 1200 to $1500 \mathrm{mg} / \mathrm{L}$ of salinity, therefore, TDS rose to more than $4000 \mathrm{mg} / \mathrm{L}$ throughout the study period fluctuating from.4110 to $4870 \mathrm{mg} / \mathrm{L}$.

Conclusion: Water quality determines to a great extent the success or failure of a fish cultural operation (Piper et al. 1982) and this research provides glimpse of the dynamics and relationship among the prime water quality characteristics in greenwater system at different timings in the day and the night. In this study we found that close to its carrying capacity, the greenwater system had an acceptable water quality for tilapia culture.

\section{REFERENCES}

APHA (1992). Standard Methods for Examination of Water and Wastewater, $18^{\text {th }}$ Edition. American Public Health Association, American Water Works Association, Water Pollution Control Federation, Washington, DC.

Atwood, H. L.; Fontenot, Q. C.; Tomasso, J. R; Isely J.J. (2001). Toxicity of nitrite to Nile tilapia: Effect of fish size and environmental chloride. North Am J Aqua 63: 49-51.

Cole, W.M.; Rakocy, J.E.; Shultz, K.A.; Bailey, D.S. (1997). Effects of solids removal on Tilapia pProduction and water quality in continuously aerated, Outdoor tanks. In Fitzsimmons K. (ed) Tilapia Aquaculture. Northeast Regional Agricultural Engineering Service, Ithaca, New York, p 373-384
Daud, S.K.; Hasbollah, D.; Law, A.T. (1988). Effect of unionized ammonia on red Oreochromis mossambicus/O. niloticus hybrid) fry. Pages 411413 In Pullin, R.S.V.; Bhukaswan, T.; Tonguthai, K.; Maclean, J. L. (ed). The Second International Symposium on Tilapia in Aquaculture. International Center for Living Aquatic Resources Management. Manila, Philippines.

Greiner, A. D.; Timmons, M.B. (1998). Evaluation of the nitrification rates of microbead and trickling filters in an intensive recirculating tilapia production facility. Aqua Eng 18:189-200.

Heinen, J M; Hankins, J.A.; Weber, A.L.; Watten, B.J. (1996). A semiclosed recirculating water system for high-density culture of rainbow trout. Prog Fish Cult 58:11-22.

Huguenin, J.E.; Colt, J. (1989). Design and Operating Guide for Aquaculture Seawater Systems. Elsevier, Amsterdam.

Lawson, T. B. (1995). Fundamentals of Aquacultural Engineering. Chapman and Hall Publishers, New York.

Leclercq, D.I.; Hopkins, K. (1985). Preliminary test of an aerated tank system for tilapia culture. Aqua Eng 4: 229-304.

Martin, J. (2000). Greenwater tank culture of tilapia. Aquap J 4: 8-11.

Piper, R. G., McElwain, I. B.; Orme, L.E.; McCraren, J.P.; Flower, L.G.; Leonard, J.R. (1982). Fish hatchery management. U. S. Fish and Wildlife Service, Washington, D.C.

Rakocy, J. E., Bailey, D. S.; Martin, J.M.; Shultz, R.C. (2000). Tilapia production systems for the lesser antilles and other resource limited tropical areas. In Fitzsimmons, K.,; Carvalho Filho J. (ed) Tilapia Culture in the 21st Century. American Tilapia Association. Rio de Jeneiro, Brazil p 651-662.

Redner, R.; Stickney, R.R. (1979). Acclimation to ammonia by Tilapia aurea. Tran Am Fish Soc 108: 383-388. 